\title{
Analisis Kesalahan dalam Penyelesaian Permasalahan Persamaan Diferensial Linier Orde Pertama: Studi Kasus Mahasiswa Teknik Telekomunikasi ITTP
}

\author{
Nurlaili $^{1^{*}}$, Utti Marina Rifanti ${ }^{2}$ \\ ${ }^{1,2}$ Institut Teknologi Telkom Purwokerto, Purwokerto, Jawa Tengah 53147, Indonesia \\ Pengiriman: 30/November/2019; Diterima: 24/Maret/2020; Publikasi: 31/Maret/2020 \\ DOI: https://doi.org/10.31629/jg.v5i1.1742
}

\begin{abstract}
Abstrak
Kemampuan menggunakan dasar keilmuan matematika dalam bidang telekomunikasi merupakan salah satu capaian pembelajaran lulusan (CPL) Program Studi Teknik Telekomunikasi Institut Teknologi Telkom Purwokerto. Penguasaan terhadap materi persamaan diferensial linier orde satu merupakan salah satu komponen penting dalam pencapaian CPL tersebut namun hasil evaluasi terhadap jawaban mahasiswa pada topik ini menunjukan tingkat kesalahan yang tinggi. Penelitian ini ditujukan untuk menganalisis kesalahan dalam penyelesaian persamaan diferensial orde satu oleh mahasiswa dan menentukan faktor-faktor penyebab kesalahan tersebut sehingga dapat mengurangi permasalahan yang sama pada masa mendatang. Penelitian menggunakan pendekatan metode deskriptif kualitatif terhadap subjek penelitian mahasiswa kelas S1TT-06-A yang dipilih melalui metode purposive sampling. Pengumpulan data menggunakan metode tes dan wawancara sedangkan analisis jawaban menggunakan panduan kriteria Watson dan menggunakan teknik triangulasi. Analisis data dilakukan dengan mereduksi data, menyajikan data dan menarik kesimpulan. Berdasarkan hasil penelitian, persentase kesalahan kategori data tidak tepat sebesar $20 \%$, ketidaktepatan prosedur sebesar $22,86 \%$, data hilang sebesar $2,85 \%$, kategori simpulan yang hilang sebesar $11,43 \%$, hirarki keterampilan sebesar 5,71\%, kategori konflik level respon dan masalah manipulasi tidak langsung sebesar $0 \%$ dan kesalahan di luar kriteria yang tujuh sebesar $14,29 \%$.
\end{abstract}

Kata kunci: analisis kesalahan; mahasiswa; persamaan diferensial linier orde pertama; kriteria Watson.

\begin{abstract}
The ability to use basic concept of mathematics in telecommunication area is one of learning outcome in Telecommunication Engineering Department of Institut Teknologi Telkom Purwokerto. The comprehensive analysis in ordinary differential equation (ODE) was the one of the key parameter to reach these learning outcome, but the errors made by student in ODE problem solving existed largely at the evaluation process. To anticipate the same problem in the next session, we designed an descriptive-qualitative research with the student of S1TT-06-A sampled by purposive sampling as research subject. To collect the data was used essay test and interview, and to analyze error in those data was used triangulation technique and Watson's criteria. Data reduction, data presentation, and conclusion was analysed. Based on the result, the errors that exist in those answer sheet consist of inappropriate data, inappropriate procedure, ommited data, ommited conclusion, respon level conflict and above other in Watson's criteria.
\end{abstract}




\section{JURNAL GANTANG. Maret 2020; V(1): 29 - 37 \\ p-ISSN. 2503-0671 \\ e-ISSN. 2548-5547}

Keywords: error analysis; student; ODE; Watson Criteria.

\section{Pendahuluan}

Pembelajaran matematika dalam dunia pendidikan memiliki urgensi yang cukup tinggi. Hal tersebut dikarenakan peranan matematika yang sangat mendasar dalam proses pembentukan kecerdasan dan karakter adaptif dari peserta didik, seperti kemampuan berpikir secara logis, rasional, kritis, cermat, jujur, efektif dan efisien (Ardiawan, 2015). Pemanfaatan ilmu matematika menyebar hampir pada seluruh keilmuan lain, termasuk keilmuan rekayasa atau teknik. Implementasi ilmu matematika dalam pembelajaran teknik merupakan keharusan karena dapat membentuk kemampuan berpikir kritis dan inovatif yang bisa dipergunakan mahasiswa untuk menyelesaikan permasalahan-permasalahan rekayasa dengan optimal. Selain bermanfaaat dalam pembentukan kemampuan berpikir mahasiswa, pembelajaran matematika juga sangat dibutuhkan karena penyelesaian permasalahan rekayasa selalu mempergunakan model matematis.

Sesuai dengan standar keilmuan rekayasa wajib, Program Studi Teknik Telekomunikasi sebagai salah satu bagian dari keilmuan rekayasa dalam bidang telekomunikasi menyelenggarakan perkuliahan dengan keilmuan matematika sebagai dasar pengetahuan. Merujuk pada kurikulum yang telah dirancang di Prodi Teknik Telekomunikasi Institut Teknologi Telkom Purwokerto, mata kuliah matematika diberikan dalam enam subjek salah satunya yaitu Kalkulus. Menurut Kamus Besar Bahasa Indonesia, kalkulus merupakan bagian dari ilmu matematika yang melibatkan tentang pengertian dan penggunaan diferensial dan juga integral suatu fungsi (Rejeki, 2015). Mata kuliah kalkulus terbagi menjadi dua bagian, yaitu kalkulus 1 dan kalkulus 2. Tujuan pembagian tersebut salah satunya agar beban materi yang disampaikan kepada mahasiswa tidak terlalu berat. Materi yang disampaikan pada mata kuliah kalkulus 1, sebagian besar berupa materi matematika dasar yang telah diperoleh pada jenjang sekolah menengah pertama dan atas. Tujuan dari pelaksanaan perkuliahan kalkulus 1 adalah agar mahasiswa dapat lebih memahami kembali tentang materi matematika dasar yang terdiri dari sistem bilangan ril, fungsi, limit, turunan, dan integral. Setelah memahami materimateri tersebut barulah mahasiswa diberikan mata kuliah kalkulus 2.

Mata kuliah kalkulus 2 merupakan dasar bagi mata kuliah lanjutan yang ada di Program Studi Teknik Telekomunikasi sehingga dilaksanakan pada tahun pertama, tepatnya pada semester kedua. Tujuan dari pelaksanaan perkuliahan kalkulus 2 adalah agar mahasiswa mampu memahami tentang materi kekonvergenan deret, turunan parsial dalam ruang dimensi $n$, integral dalam ruang dimensi $n$, dan persamaan diferensial. Dari beberapa materi tersebut, bagian dari mata kuliah kalkulus 2 yang sangat berkaitan dengan mata kuliah lainnya adalah materi persamaan diferensial (Telekomunikasi, 2018).

Persamaan diferensial merupakan inti dari keilmuan analisis matematika dan menjadi bagian penting dalam kalkulus terutama untuk memahami ilmu-ilmu yang berkaitan dengan sains termasuk Teknik (Simons, 2017). Persamaan diferensial linier orde pertama merupakan persamaan diferensial yang memiliki bentuk paling sederhana, karena turunan tertingginya adalah turunan pertama sedangkan penyelesaiannya menggunakan konsep turunan dan integral. Dalam kurikulum Teknik Telekomunikasi, analisis permasalahan dengan menggunakan persamaan diferensial linier orde pertama mulai diperkenalkan pada mata kuliah tahun pertama seperti Fisika atau Rangkaian Listrik pada topik pembahasan analisis rangkaian Resistor-Capacitor. Persamaan diferensial linier orde pertama ini juga banyak digunakan dalam memodelkan berbagai permasalahan sehari-hari walaupun bentuknya sederhana. Namun 
kegagalan memahami konsep turunan dan integral yang dibutuhkan dalam penyelesaian persamaan diferensial menjadi bentuk kesalahan yang banyak terjadi berdasarkan observasi yang dilakukan oleh Haswati (Haswati \& Nopitasari, 2019). Observasi lebih lanjut dalam kesalahan penyelesaian persamaan diferensial di Teknik Telekomunikasi ditujukan untuk melihat keterkaitan dengan penelitian Haswati. Kesederhanaan dari persamaan diferensial linier orde satu yang hanya melibatkan pemahaman integral dan turunan diharapkan mampu mendorong mahasiswa untuk menguasai materi tersebut sehingga mudah mengerjakan masalahmasalah yang berkaitan dengan persamaan diferensial.

Namun kemampuan mahasiswa dalam menyerap materi yang diajarkan memiliki variasi yang beragam (Rosmaiyadi, 2018). Sebagian mahasiswa yang berkemampuan tinggi dapat menyerap materi ajar yang disampaikan oleh dosen dengan mudah. Mahasiswa yang berkemampuan tinggi akan mudah untuk menyelesaiakn soal-soal yang diberikan baik berupa tugas, kuis, ujian tengah dan akhir semester. Pada kelompok ini tidak akan banyak ditemukan kesalahan dalam penyelesaian soalsoal yang diberikan oleh dosen. Sedangkan kelompok mahasiswa yang berkemampuan rendah menghadapi kesulitan dalam memahami materi yang disampaikan oleh dosen. Sehingga kelompok ini belum dapat menyerap materi pembelajaran secara optimal.

Indikator yang bisa dilihat dari ketidakterserapan materi secara optimal yaitu tingginya tingkat kesalahan dalam penyelesaian soal seperti kesalahan pengambilan data, kesalahan operasi, kesalahan penggunaan rumus dan masih banyak lagi kesalahan yang mungkin dilakukan mahasiswa. Tingginya tingkat kesalahan yang terjadi menggambarkan ketercapaian sasaran dalam pembelajaran persamaan diferensial masih rendah sehingga pemahaman mahasiswa terhadap topik ini juga rendah. Dalam rangka meminimalisir kesalahan tersebut agar capaian pembelajaran terpenuhi secara optimal, kami melakukan analisis terhadap kesalahan yang sering dilakukan oleh mahasiswa dalam menjawab soal-soal. Analisis terhadap kesalahan ini dilakukan agar dapat meningkatkan kualitas dalam proses pembelajaran di kelas (Munawaroh, Rohaeti, \& Aripin, 2018)

Analisis yang kami gunakan untuk menganalisis kesalahan mahasiswa adalah dengan menggunakan analisis kesalahan berdasarkan kriteria Watson. Kriteria kesalahan menurut watson ada 8 yaitu data tidak tepat, prosedur tidak tepat, data hilang, kesimpulan hilang, konflik level respon, manipulasi tidak langsung, masalah hirarki keterampilan, selain dari ketujuh kriteria kesalahan tersebut (Nur, Aisyah, Hariyani, Nur, \& Dinullah, 2019)

Berdasarkan hasil dari ujian semester berkaitan dengan soal persamaan diferensial linier orde pertama diperoleh data bahwa dari 35 mahasiswa ada 8 orang mahasiswa yang menjawab dengan benar, 22 orang yang jawabannya kurang benar dikarenakan ada beberapa kesalahan yang mereka lakukan, serta 5 orang lagi tidak menjawab dan hanya menyalin soal. Analisis jawaban menunjukkan bahwa terdapat banyak kesalahan yang dilakukan mahasiswa dalam proses mengerjakan soal berkaitan dengan persamaan diferensial linier orde pertama. Stelah didapat data di atas maka dilakukan analisis kepada 22 orang mahasiswa berdasarkan kriteria Watson.

Analisis terhadap kesalahan yang dilakukan mahasiswa ini sangatlah penting terutama bagi mahasiswa yang memiliki kemampuan belajar rendah (Salvia, Ysseldyke, \& Bolt, 2011). Analisis yang kami lakukan bertujuan mengetahui kesalahan apa saja yang sering dilakukan mahasiswa dan faktor apa saja yang menyebabkan kesalahan yang dilakukan oleh mahasiswa tersebut. Hal ini akan membuat dosen dengan mudah untuk menentukan metode atau cara belajar yang sesuai dengan kebutuhan 
JURNAL GANTANG. Maret 2020; V(1): 29 - 37

p-ISSN. 2503-0671

e-ISSN. 2548-5547

mahasiswa. Diharapkan dengan adanya informasi tersebut, dosen dapat mencari stategi dalam pembelajaran yang dapat memperkecil terjadinya kesalahan tesebut, sehingga permasalahan serupa tidak terulang (Huljannah, Sugita, \& Anggraini, 2015). Setelah analisis dilakukan terhadap kesalahan mahasiswa, maka hal yang dilakukan berikutnya adalah menentukan faktor yang menyebabkan mahasiswa melakukan kesalahan tersebut.

Berdasarkan hasil wawancara yang dilakukan dengan beberapa mahasiswa diperoleh informasi bahwa kesalahan yang dilakukan disebabkan oleh faktor dari dalam dan faktor dari luar. Faktor yang berasal dari dalam misalnya pada saat di kelas mereka paham dengan materi tersebut namun pada saat ujian mereka lupa cara menyelesaikannya, kurang paham terhadap konsep integral, kurang teliti dalam melihat soal, tidak memahami cara penyelesaian persamaan diferensial.

Faktor lain adalah faktor dari luar seperti kondisi lingkungan, keluarga teman dan alat belajar. Mahasiswa menyampaikan bahwa keluarga juga merupakan salah satu faktor kesulitan mereka belajar, dimana pada saat mau belajar sering diganggu oleh adeknya sehingga tidak fokus belajar. Kurangnya alat belajar terutama buku juga menyebabkan mereka kurang memahami materi sehingga menyebabkan banyak melakukan kesalahan dalam mengerjakan soal.

Berdasarakan penelitian yang dilakukan oleh Isran dalam Isran (2017) mengidentifikasi jenis kesalahan terbanyak yang dilakukan mahasiswa yaitu kesalahan prosedur tidak tepat sebanyak $75 \%$ dan paling sedikit adalah pada kategori data hilang sebesar 3,85\%. Pada kategori konflik level respon dan data tidak tepat tidak ditemukan kesalahan.

Penelitian lain mengenai analisis kesalahan juga dilakukan oleh Dwinata (Dwinata \& Ramadhona, 2018), diperoleh informasi bahwa kesalahan yang paling banyak dilakukan mahasiswa adalah reading dan comprehension yang menunjukkan rendahnya kemampuan

mahasiswa dalam membaca dan memahami permasalahan.

\section{Metode Penelitian}

Analisis kesalahan mahasiswa dalam penelitian ini menggunakan pendekatan deskriptif kualitatif untuk memberikan gambaran tentang kesalahan yang dilakukan oleh mahasiswa dalam menyelesaikan persamaan diferensial linier orde pertama. Penelitian ini dilakukan pada mahasiswa tahun pertama prodi S1 Teknik Telekomunikasi, kelas A semester dua dengan jumlah populasi sebesar 38 orang.

Teknik pengumpulan data yang dilakukan meliputi tes tertulis dan wawancara. Tes tertulis dilakukan pada akhir semester. Jumlah soal yang digunakan ada sebanyak 3 soal, meliputi soal turunan dalam ruang dimensi n, integral lipat dan persamaan diferensial linier orde pertama. Sebelum melaksanakan ujian akhir semester maka dilakukan diskusi bersama dengan dosen lain yang mengampu mata kuliah kalkulus 2 untuk melihat validitas isi dari segi kesesuaian butir soal dengan kisi-kisi dan juga dari segi bahasa yang digunakan.

Setelah mahasiswa melaksanakan ujian akhir semester maka dilakukan proses penilaian terhadap hasil kerja mahasiswa. Hasil yang diperoleh bahwa banyak mahasiswa yang mendapatkan poin rendah untuk soal pada nomor 3 yang berkaitan dengan soal persamaan diferensial linier orde pertama. Sehingga perlu dilakukan analisis terhadap soal tersebut untuk mengetahui kesalahan yang dilakukan mahasiswa dan faktor penyebabnya untuk meminimalisir kesalahan di masa yang akan datang.

Wawancara dilakukan setelah adanya analisis terhadap lembar jawaban mahasiswa. Tujuan dari wawancara adalah untuk mengetahui penyebab terjadinya kesalahan yang dilakukan oleh mahasiswa. Pertanyaan yang diajukan pada saat melakukan wawancara dengan mahasiswa adalah (1) tanggapan mahasiswa terhadap soal yang diberikan, (2) kendala yang dihadapi pada saat menjawab soal, (3) pemahaman mahasiswa terhadap materi yang berkaitan persamaan 
diferensial linier orde pertama (4) bagian tersulit bagi mahasiswa dalam menyelesaikan persamaan linier diferensial orde pertama. (5) penyebab mahasiswa melakukan kesalahan dalam menjawab soal.

Instrumen yang digunakan dalam penelitian ini adalah berupa soal tes dan pedoman wawancara. Soal tes yang diujikan berupa soal uraian. Sedangkan pedoman wawancara berisi daftar pertanyaan yang ditanyakan pada saat melakukan wawancara dengan mahasiswa.

Analisis data dilakukan dengan triangulasi data melalui beberapa tahapan yaitu tahapan mereduksi data meliputi pemeriksaan terhadap hasil jawaban mahasiswa. Hasil ini dijadikan bahan untuk wawancara sehingga dapat diketahui penyebab terjadinya kesalahan tersebut. Tahapan selanjutnya adalah penyajian data meliputi menganalisis jawaban dan hasil wawancara mahasiswa. Metode analisis kesalahan dari jawaban mahasiswa menggunakan kriteria Watson. Kesalahan yang dianalisis ada 8 kriteria yaitu kesalahan data tidak tepat (inappropriate data/id), kesalahan prosedur tidak tepat (inappropriate procedure/ip), kesalahan data hilang (omitted data/od), kesalahan kesimpulan hilang (omitted conclusion/oc), konflik level respon (response level conflict/rlc), manipulasi tidak langsung (undirected manipulation/um), masalah hirarki keterampilan (skills hierarchy problem/shp) dan selain dari ketujuh kriteria kesalahan tersebut (above other/ao) (Ningsih, Hariyani, \& Fayeldi, 2019). Tahapan terakhir yang dilakukan adalah menarik kesimpulan dari analisis yang telah dilakukan.

\section{Hasil dan Pembahasan}

Fokus pembahasan dalam analisis kesalahan yang dilakukan mahasiswa dipusatkan pada soal persamaan diferensial khususnya penyelesaian persamaan diferensial linier orde pertama. Secara umum, persamaan diferensial linier orde pertama didefinisikan dalam persamaan $\frac{d y}{d x}+p(x) y=Q(x)$. Penyelesaian persamaan diferensial linier orde pertama memiliki dua solusi yaitu solusi umum dan solusi khusus. Analisis kesalahan dalam penelitian ini dilaksanakan dengan mengamati jawaban mahasiswa hingga menghasilkam solusi umum dan solusi khusus.

Tes tertulis untuk materi persamaan diferensial linier orde pertama dilaksanakan pada hari Senin tanggal 15 Juli 2019 dan diikuti oleh 35 mahasiswa. Setelah mahasiswa mengikuti ujian semester lembar jawaban tersebut kemudian diperiksa dan diperoleh hasil 8 orang mahasiswa $(22,86 \%)$ memiliki jawaban sesuai dengan prosedur penyelesaian persamaan diferensial linier orde pertama, 5 orang $(14,29 \%)$ yang hanya menuliskan soal pada lembar jawaban dan 22 orang $(62,85 \%)$ mahasiswa yang memiliki jawaban kurang sempurna karena terdapat beberapa kesalahan dalam penyelesaiannya.

Analisis kesalahan dilakukan terhadap jawaban yang diberikan oleh 22 orang mahasiswa yang memiliki kesalahan pada saat mengerjakan soal yang diberikan dan 5 orang yang hanya menuliskan soal saja. Kesalahan ini dianalisis berdasarkan kategori menurut Watson. Berikut ini diberikan persentase kesalahan mahasiswa menurut Watson yang disajikan dalam Tabel 1 .

Tabel 1.

Tabel analisis kesalahan menurut kriteria Watson.

\begin{tabular}{lc}
\hline Analisis Kesalahan & $\begin{array}{l}\text { Persentase } \\
\text { kesalahan }\end{array}$ \\
\hline $\begin{array}{l}\text { Data tidak tepat (inappropriate } \\
\text { data/ip) }\end{array}$ & $20 \%$ \\
\hline $\begin{array}{l}\text { Prosedur tidak tepat (inappropriate } \\
\text { procedurel ip) }\end{array}$ & $22,86 \%$ \\
\hline Data hilang (ommited data / od) & $2,85 \%$ \\
\hline $\begin{array}{l}\text { Kesimpulan hilang (ommited } \\
\text { conclusion /oc) }\end{array}$ & $11,43 \%$ \\
\hline $\begin{array}{l}\text { Konflik level respon (response level } \\
\text { conflict/ rlc) }\end{array}$ & $0 \%$ \\
\hline $\begin{array}{l}\text { Manipulasi tidak langsung } \\
\text { (undirected manipulation/ um) }\end{array}$ & $0 \%$ \\
\hline $\begin{array}{l}\text { Masalah hirarki keterampilan (skill } \\
\text { hierarchy problem/shap) }\end{array}$ & $5,71 \%$ \\
\hline $\begin{array}{l}\text { Selain ketujuh kategori di atas } \\
\text { (above other/ao) }\end{array}$ & $14,29 \%$ \\
\hline
\end{tabular}


JURNAL GANTANG. Maret 2020; V(1): 29 - 37

p-ISSN. 2503-0671

e-ISSN. 2548-5547

Berdasarkan Tabel 1 kesalahan pertama yang ditemukan adalah pengambilan data tidak tepat. Kesalahan ini pada saat mahasiswa melakukan kesalahan dalam mengambil data yang akan digunakan untuk menyelesaiakan soal yang diberikan. Persentase kesalahan ini sebesar $20 \%$. Contoh salah satu jawaban mahasiswa terdapat pada Gambar 1.

1) $P=-1$
2) $F I=e^{\int P d x}=e^{\int-1}=e^{-x}$
3) $e^{-x} \cdot \frac{d y}{d x}-e^{-x} \cdot 3 y=e^{-x} \cdot x e^{3 x}$
$\Leftrightarrow \frac{d y}{d x}-e^{-x} \cdot 3 y=x e^{3 x}$

Gambar 1. Jawaban mahasiswa IZ

Kesalahan mahasiswa IZ berdasarkan Gambar 1 terjadi pada saat mahasiswa melakukan kesalahan dalam menentukan nilai $\mathrm{P}(\mathrm{x})$ yang digunakan untuk menentukan faktor integral. Mahasiswa menuliskan bahwa nilai $\mathrm{P}(\mathrm{x})$ adalah 1 , seharusnya nilainya adalah -3 . Kesalahan pada tahap awal ini akan menyebabkan terjadinya kesalahan yang berkelanjutan dalam proses penyelesaian persamaan diferensial tersebut. Dimana setiap langkah dalam penyelesaian persamaan diferensial saling terkait dengan langkah berikutnya. Hal ini sejalan dengan pernyataan Huljannah (Huljannah et al., 2015) bahwa data hilang menyebabkan penyelesaian soal tidak lengkap. Berdasarkan wawancara yang dilakukan dengan mahasiswa tersebut diperoleh informasi bahwa penyebab dari kesalahan pada pengambilan data ini adalah karena mahasiswa kurang teliti dalam membaca soal dan terburuburu ingin menyelesaikannya.

Kesalahan kedua yang ditemukan adalah adanya prosedur tidak tepat dalam proses penyelesaian. Kesalahan prosedur tidak tepat pada penelitian ini meliputi kesalahan pada saat menyelesaikan perhitungan integral. Persentase kesalahan prosedur tidak tepat ini ditemukan sebesar $22,86 \%$. Salah satu contoh jawaban mahasiswa terdapat pada Gambar 2.

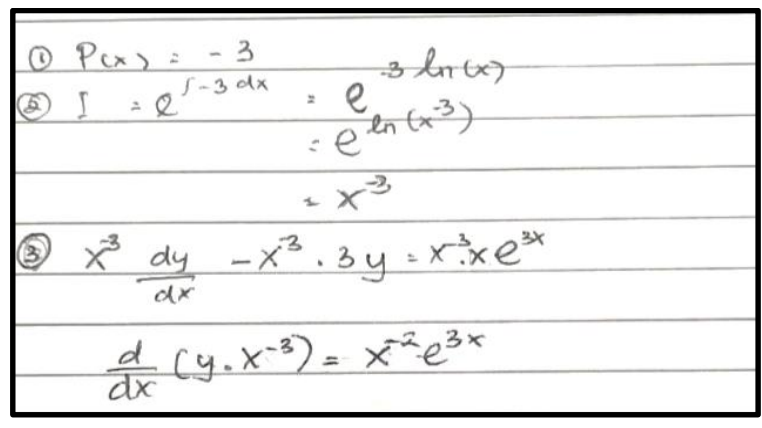

Gambar 2. Jawaban mahasiswa NI

Kesalahan yang ditemukan pada jawaban mahasiswa NI adalah kesalahan pada saat menghitung integral pada faktor integral. Mahasiswa menghitung bahwa $e^{\int-3 d x}$ adalah $e^{-3 \ln x}$ dan hasil akhirnya dituliskan $x^{-3}$. Sedangkan jawaban yang tepat dari $e^{\int-3 d x}$ adalah $e^{-3 x}$. Berdasarkan wawancara yang dilakukan dengan mahasiswa NI diperoleh informasi bahwa kesalahan tersebut terjadi karena mahasiswa NI kesulitan untuk menyelesaikan integral pada pangkat fungsi eksponensial. NI berfikir bahwa kalau ada fungsi berbentuk eksponensial maka penyelesaiannya akan menghasilkan $\ln$.

Kesalahan ketiga berupa data hilang dengan persentase sebesar 2,85\%. Kesalahan data hilang yang dimaksud adalah pada saat mahasiswa menyelesaikan persamaan diferensial linier orde pertama ada informasi yang hilang dari proses pengerjaannya. Contoh jawaban mahasiswa dapat dilihat pada Gambar 3.

1) $P=-3$
3) $f_{1}=-3 x$
3) $(-3 x) \cdot \frac{d y}{d x}-3 y(-3 x)=x e^{1 x} \cdot(-3 x)$
$\Rightarrow \quad-3 x=\frac{d}{d x}(y, 3 y)(-3 x)=-3 x e^{3 x}$

Gambar 3. Jawaban mahasiswa BD

Kesalahan yang dilakukan mahasiswa BD adalah pada saat menuliskan faktor integral ada informasi yang hilang, seharusnya bentuk faktor integral $e^{-3 x}$ namun mahasiswa hanya 
menuliskan $-3 x$ saja. Hal ini juga akan berpengaruh pada penyelesaian berikutnya.

Berdasarkan wawancara yang dilakukan dengan mahasiswa BDW diperoleh informasi bahwa penyebab terjadinya kesalahan tersebut adalah karena mahasiswa BD hanya mengingat bahwa pada saat menentukan faktor integral adalah dengan mengintegralkan $\mathrm{P}(\mathrm{x})$ yang telah ditentukan sebelumnya. BD lupa bahwa bentuk dari faktor integral itu adalah $e^{\int P(x) d x}$ (Purcell \& Varberg, 2016).

Kesalahan keempat yang ditemukan adalah hilangnya kesimpulan dengan persentase $11,43 \%$. Hilangnya kesimpulan yang dimaksud pada penelitian ini adalah pada saat mahasiswa tidak menyelesaikan sampai hasil akhir yang ditanyakan pada soal serta salah dalam memberikan kesimpulan.

Berdasarkan Gambar 4 terlihat bahwa mahasiswa TD telah melakukan prosedur penyelesaian persamaan diferensial linier orde pertama sampai menemukan solusi umumnya dengan benar. Mahasiswa TD langsung memberikan kesimpulan bahwa solusi umum yang diperoleh adalah solusi khusus yang diminta dalam soal. Padahal solusi khusus yang dimaksud soal diperoleh dari substitusi nilai yang diketahui ke dalam solusi umum yang telah didapatkan. Berikut contoh jawaban mahasiswa pada Gambar 4.

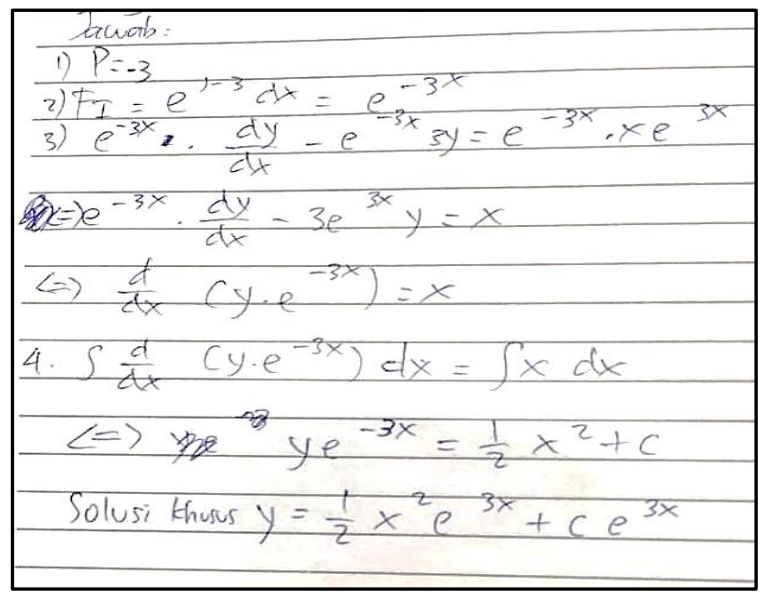

Gambar 4. Jawaban mahasiswa TD
Berdasarkan hasil wawancara yang dilakukan dengan mahasiswa TD diperoleh informasi bahwa faktor penyebab kesalahan tersebut adalah kurang teliti dalam membaca soal. Mahasiswa TD tidak memperhatikan adanya nilai $\mathrm{x}$ dan y di soal yang akan disubstitusikan ke persamaan, sehingga setelah menemukan solusi umum maka mahasiswa TD langsung menyimpulkan bahwa jawaban yang diperolehnya tersebut adalah jawaban yang diminta pada soal.

Kesalahan kelima dan keenam menurut kriteria Watson adalah kesalahan konflik level respon dan manipulasi tidak langsung. Persentase kedua kesalahan ini masing-masing sebesar $0 \%$. Kesalahan konflik level respon dan manipulasi tidak langsung tidak ditemukan dalam jawaban mahasiswa setelah dilakukan analisis.

Kesalahan ketujuh yang ditemukan adalah kesalahan hirarki keterampilan. Persentase kesalahan ini sebesar 5,71 \%. kesalahan yang dimaksud adalah keterampilan mahasiswa untuk melakukan perkalian aljabar masih kurang. Salah satu jawaban mahasiswa dapat dilihat pada Gambar 5.

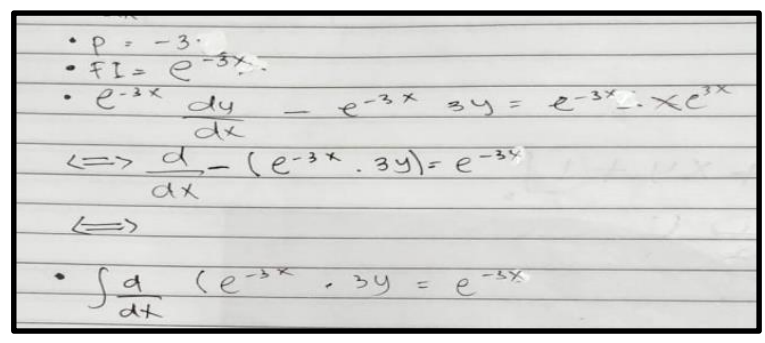

Gambar 5. Jawaban mahasiswa FI

Jawaban dari mahasiswa FI pada Gambar 5 , terlihat bahwa pada langkah ketiga di ruas kanan dimana pada saat menghitung $e^{-3 x} \cdot x \cdot e^{3 x}$ seharusnya menghasilkan $x$ saja, namun mahasiswa FI menuliskan hasilnya $e^{-3 x}$. Berdasarkan wawancara yang dilakukan dengan mahasiswa FI diketahui bahwa penyebab terjadinya kesalahan tersebut adalah karena ia bingung cara mengalikan persamaan bentuk eksponensial. 
Selain ketujuh bentuk kesalahan yang telah dijelaskan pada bagian sebelumnya, kami juga menemukan kesalahan-kesalahan lain dimana adanya ketidaksesuaian langkah penyelesaian dengan langkah yang diharapkan. Berdasarkan wawancara yang dilakukan dengan salah seorang mahasiswa yaitu DM diketahui bahwa pada saat dosen menjelaskan materi tentang penyelesaian persamaan diferensial linier orde pertama di kelas, ia memahami apa yang disampaikan namun pada saat ujian dia lupa cara penyelesaiannya. DM juga mengakui bahwa dia kurang mengerjakan latihan sehingga dia mengalami kesulitan pada saat ujian.

Kesalahan lain yang juga ditemukan di luar kriteria di atas adalah ada mahasiswa yang hanya menuliskan kembali soal yang diberikan, tanpa adanya usaha untuk mencoba mencari jawaban dari persoalan yang diberikan. Berdasarkan wawancara yang dilakukan diperoleh informasi bahwa mahasiswa tersebut tidak memahami materi tentang penyelesaian persamaan diferensial linier orde pertama. Namun pada saat di kelas mahasiswa ini malu untuk bertanya kepada dosen. Sementara di rumah dia juga tidak bisa belajar karena sering diganggu oleh adiknya.

Pada penelitian ini hanya ditemukan 6 kesalahan yang dilakukan oleh mahasiswa dari 8 kesalahan berdasarkan kriteria Watson dimana kesalahan konflik level respon dan manipulasi tidak langsung tidak ditemukan. Hasil penelitian serupa dilakukan oleh Ningsih yang menemukan 6 kesalahan yang dilakukan oleh siswa yaitu kesalahan data tidak tepat, prosedur tidak tepat, data hilang, kesimpulan hilang dan masalah hirarki keterampilan (Ningsih et al., 2019). Pada penelitian Ningsih manipulasi tidak langsung dan kesalahan selain dari tujuh kriteria yang lain tidak ditemukan. Penelitian lain juga dilakukan oleh Saputri yang menemukan semua jenis kesalahan berdasarkan kriteria Watson yang dilakukan oleh siswa dan analisis kesalahan dilakukan berdasarkan perbedaan gender (Saputri, Sugiarti, Pratama, Trapsilasiwi, \& Yudianto, 2018).
Terdapat perbedaan antara penelitian ini dengan penelitian sebelumnya diantaranya dari segi materi, jenjang pendidikan, faktor penyebab terjadinya kesalahan dan jenis kesalahan yang ditemukan. Pada penelitian ini analisis dilakukan pada materi persamaan diferensial linier orde pertama yang diberikan kepada mahasiswa, sedangkan Ningsih melakukan analisis terhadap siswa MTsN pada materi lingkaran (Ningsih et al., 2019) dan Saputri melakukan analisis pada siswa SMP kelas VIII pada materi fungsi (Saputri et al., 2018).

Hal yang dapat kita lakukan untuk meminimalisir kesalahan-kesalahan dalam menyelesaikan masalah berkaitan dengan persamaan diferensial linier orde pertama di atas adalah memperkuat konsep mahasiswa mengenai integral dan turunan karena ini menjadi dasar bagai mahasiswa untuk menyelesaikan persamaan diferensial linier orde pertama. Memperbanyak latihan bagi mahasiswa juga dapat membantu mahasiswa lebih terbiasa dalam menyelesaikan soal-soal dan tidak mudah lupa dengan langkah-langkah penyelesaian dari persamaan diferensial linier orde pertama. Hal lain yang bisa dilakukan adalah lebih menekankan kepada mahasiswa dalam menentukan faktor integral. Hal ini sangat penting dilakukan karena pada saat mahasiswa salah dalam menetapkan faktor integral maka akan berdampak terhadap proses berikutnya sehingga menyebabkan ketidaksesuaian dengan hasil akhir.

\section{Kesimpulan}

Berdasarkan hasil analisis yang dilakukan terhadap kesalahan mahasiswa dalam menyelesaikan materi persamaan linier orde pertama dengan menggunakan kriteria Watson diperoleh bahwa penyebab kesalahan terbesar mahasiswa adalah prosedur yang tidak tepat, yaitu sebesar 22.86\%. Dalam hal ini, kesalahan prosedur yang tidak tepat meliputi kesalahan pada saat menyelesaikan integral. Selain itu, berdasarkan wawancara yang dilakukan diperoleh informasi bahwa faktor yang menyebabkan terjadinya kesalahan mahasiswa saat menjawab 
soal sebagian besar berasal dari faktor kurangnya ketelitian dalam membaca dan memahami soal, kurang memahami konsep materi yang diberikan, malu bertanya apabila ada yang tidak dipahami, kurang mengerjakan latihan sehingga mudah lupa. Bagi peneliti yang lain dapat melanjutkan penelitian ini dengan merancang pembuatan bahan ajar persaaman diferensial linier orde pertama.

\section{Ucapan Terimakasih}

Ungkapan terima kasih penulis sampaikan kepada mahasiswa kelas S1 TT-06-A yang telah bersedia menjadi objek penelitian.

\section{Referensi}

Ardiawan, Y. (2015). Analisis kesalahan mahasiswa dalam menyelesaikan soal induksi matematika di IKIP PGRI Pontianak. Jurnal Pendidikan Informatika Dan Sains, 4(1), 147-163.

Dwinata, A., \& Ramadhona, R. (2018). Analisis kesalahan siswa dalam pemecahan problematika kaidah pencacahan titik sampel. Jurnal Gantang, 3(2), 117-126. https://doi.org/10.31629/jg.v3i2.479

Haswati, D., \& Nopitasari, D. (2019). Implementasi bahan ajar persamaan diferensial dengan metode guided discovery berbantuan software mathematica untuk meningkatkan pemahaman konsep. Jurnal Gantang. 4(2), 97-102. https://doi.org/10.31629/jg.v4i2.1358

Huljannah, M., Sugita, G., \& Anggraini. (2015). Analisis kesalahan siswa dalam menyelesaikan soal persamaan dan identitas trigonometri berdasarkan kriteria watson di kelas X SMA Al-Azhar Palu. Jurnal Pendidikan Matematika, 4(2), 164-176.

Isran. (2017). Analisis kesalahan siswa dalam menyelesaikan tes kemampuan berfikir kritis materi fungsi eksponen dengan panduan kriteria watson. Kontinu Jurnal Pendidikan Didaktik Matematika,1(1), 4357. http://dx.doi.org/10.30659/kontinu.1.1.43$\underline{57}$

Munawaroh, N., Rohaeti, E. E., \& Aripin, U. (2018). Analisis kesalahan siswa berdasarkan kategori kesalahan menurut watson dalam menyelesaikan soal komunikasi matematis siswa SMP. Jurnal Pembelajaran Matematika Inovatif, 1(5), 993-1004.

Ningsih, N., Hariyani, S., \& Fayeldi, T. (2019). Analisis kesalahan siswa dalam menyelesaikan soal lingkaran berdasarkan kategori watson. UNION: Jurnal Pendidikan Matematika, 7(2), 187-200.

Nur, F., Aisyah, K., Hariyani, S., Nur, R., \& Dinullah, I. (2019). Analisis kesalahan penyelesaian soal cerita berdasarkan kriteria watson. Jurnal Review Pembelajaran Matematika, 4(1), 1122. https://doi.org/10.15642/jrpm.2019.4.1. 11-22

Nurhikmah, S., \& Febrian, F. (2016). Analisis kesalahan siswa dalam menyelesaikan permasalahan integral tak tentu. Jurnal Tatsqif, 14(2). https://doi.org/10.20414/jtatsqif.v14i2.1074

Purcell, E. ., \& Varberg, D. (2016). Calculus with analytic geometry, 5th Edition (5th ed.; N. I. Susila, B. Kartasasmita, \& Rawuh, Eds.). Jakarta: Erlangga.

Rejeki, S. (2015). Kontribusi kemampuan kalkulus i dan kalkulus ii terhadap hasil belajar mata kuliah analisis vektor. JPM IAIN Antasari, 3(1), 1-14. https://doi.org/10.1017/CBO978110741532 4.004

Rosmaiyadi. (2018). Analisis kesalahan penyelesaian soal aljabar pada mahasiswa program studi pendidikan matematika STKIP Singkawang. Jurnal Pendidikan Matematika, 12(1), 59-70.

Salvia, J., Ysseldyke, J., \& Bolt, S. (2011). Assessment: in special and inclusive education (11th ed.). Belmont: Wadsworth.

Saputri, R. R., Sugiarti, T., Pratama, R., Trapsilasiwi, D., \& Yudianto, E. (2018). Analisis kesalahan siswa dalam menyelesaikan soal materi fungsi berdasarkan kriteria watson ditinjau dari perbedaan gender siswa SMP kelas VIII. Kadikma, 9(2), 59-68.

Simons, G. E. (2017). Differential equations with applications and historical notes (3rd ed.). Boca Raton: CRC Press.

Telekomunikasi, T. (2018). Kurikulum teknik telekomunikasi tahun 2018. Purwokerto. 
JURNAL GANTANG. Maret 2020; V(1): 29 - 37

p-ISSN. 2503-0671

e-ISSN. 2548-5547 